\title{
Improving Work Productivity Through Training, Discipline And Communication At PT. Linewin
}

\author{
Martin $^{1 *}$,Dewi Rafiah Pakpahan ${ }^{2}$ \\ ${ }^{1}$ Accounting Computerization Lecturer, PoliteknikUnggul LP3M \\ North Sumatra Indonesia. \\ ${ }^{2}$ Lecturers of STIE MahkotaTricomUnggul \\ North Sumatra Indonesia \\ ${ }^{*}$ Corresponding author: \\ Email:m4rt1n.myrafa@gmail.com
}

\begin{abstract}
.
The purpose in this study is to analyze the influence of both partial and simultaneous training, discipline and communication on productivity. This research was conducted on PT. Linewin selected 117 production employees to sample. data collection using questionnaires with data analysis using SPSS 22.

The results showed that training, discipline and communion had a positive and significant effect on productivity in PT. Linewin. Discipline variables have the most dominant influence in improving employee work productivity in PT. Linewin. Furthermore, the result of a determination coefficient of $69.1 \%$ of productivity variables can be explained by variations in training, discipline and communication variables and the remaining $40.9 \%$ is another variable not studied in this study
\end{abstract}

Keywords: Training,Discipline, Communication, Productivity

\section{INTRODUCTION}

PT. Linewin is a company engaged in the manufacturing of eco-friendly wood with the utilization of raw materials of rubber wood plantations to meet the global market. Based on observations thatresearchers do that employee productivity is not yet maximal. Productivity PT. Linewin employees during January-September 2017 experienced volatile, this is seen in the picture as follows:

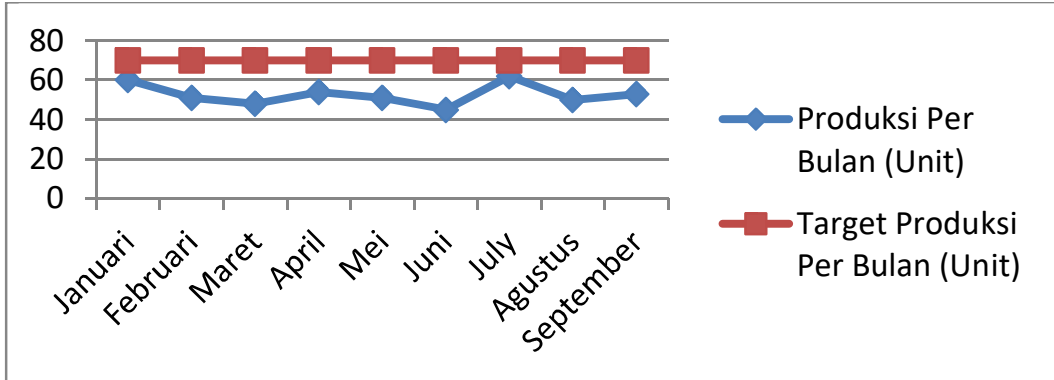

Figure 1.Relialization of Production

From the image data can be seen that monthly production in January 2017 amounted to 60 $(85.7 \%)$ unit and still far from the target specified which is $70(100 \%)$ monthly, further decreased because it is not able to produce rubber wood according to the target set. In February it decreased by $51(72.8 \%)$ unit and decreased again in March to 48 (68.5\%) unit, until September was volatile because it was only able to produce $53(75.7 \%)$ Unit. Productivity reviewed from effectiveness and efficiency of work has not led to maximum work achievement, this is shown from the un achievement of targets related to

The lack of maximum employee work productivity is due to the lack of skills and ability of employees through job training programs. During this time the training in PT. Linewin is an employee only trained directly when working. Most senior employees or older employees teach the new employee. Whereas in the production process, management has determined the target stipulated by the 
company. So because of the job training that is not maximal it causes production targets not to be achieved. Good training will be able to increase employee work productivity [1][2][3].

Then the discipline of work at PT. Linewin is still lacking discipline. Where employees often skip work suddenly on the grounds that there is a specific need. So this causes newly recruited employees not to have many opportunities to learn from old employees in carrying out their work activities. This is why when the newly recruited employee is having work problems feel confused to ask whom. From this problem has an impact on the number of production defect products. A good work displin will be able to increase employee work productivity[4][5][6][7].

The last communication problem is from top to bottom. So far complaints felt by employees have not been responded to properly especially by management. This makes everything that the company's existing system improvements don't go as expected. Conditions that can occur while employees in the production section have a problem in completing their work. Good communication will make coordination between one employee and another more effective. This will increase the productivity of existing work in an organization [8][9][10].

\section{METHODS}

Quantitative research was chosen by the authors because it was considered most appropriate to the topic discussed. The variables in this study consist of productivity also known as dependent variables as well as training, discipline and communication included in independent variables. The population and samples in this study are employees of the production section at PT. Linewin has 117 employees. Data collection through questionnaires.data analysis using SPSS 22.

\section{RESULT AND DISCUSSION Classic Assumption Test \\ Data Normality Test}

The results of the tests are as follows:

\begin{tabular}{|ll|l|}
\hline \multicolumn{2}{|c|}{ Table 1. One-Sample Kolmogorov-Smirnov Test } \\
\hline \multicolumn{2}{|c|}{} & $\begin{array}{c}\text { Unstandardized } \\
\text { Predicted Value }\end{array}$ \\
\hline Normal Parameters ${ }^{\mathrm{a}, \mathrm{b}}$ & Mean & 117 \\
& Std. Deviation & 1.81320828 \\
Most Extreme Differences & Absolute & .115 \\
& Positive & .115 \\
& Negative & -.110 \\
Test Statistic & .115 \\
Asymp. Sig. (2-tailed) & $.075^{\mathrm{c}}$ \\
\hline A. Test distribution is Normal. \\
\hline B. Calculated from data. \\
\hline c. Lilliefors Significance Correction. \\
\hline
\end{tabular}

The results in kolmogorov Smirnov's normality test in the table above show a significant value of 0.075 and above a significant value of 0.05 , in other words a normal distributed residual variable.

\section{Multicolineity Test}

The multiconsistidal test results in this study are a VIF value for free variables of 1,384 smaller than $10(\mathrm{VIF}<10)$ and the tolerance value for training variables is $0.722>0.10$, respectively, for discipline variables of $0.322>0.10$ as well as $0.430>0.10$ omunication variables. Thus, the regression equation is free from the assumption of multicolinerity

\section{Heteroskedastisity Test}

The results of the tests that have been done are as follows: 


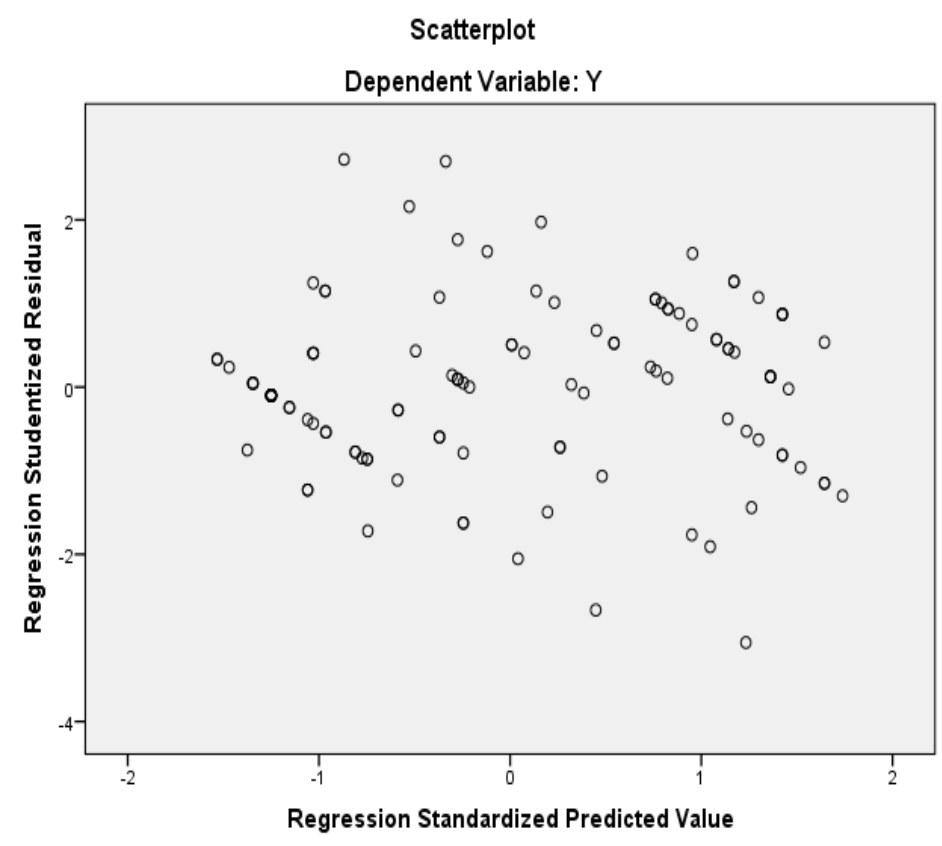

Figure 2. Heteroskedastisity Test Results

Figure 2 above shows that the resulting dots spread randomly and do not form a specific pattern or trend line. The image above also shows that the data spread is around the zero point. The results of this test showed that this regression model is free of heteroskedasticity problems, in other words: the variables that will be tested in this study are homokedastis.

\section{Multiple Linear Regression Analysis}

The results of the regression analysis in this study are as follows:

Table 2. Multiple Linear Regression Analysis Results

\begin{tabular}{|c|c|c|c|c|c|c|c|c|}
\hline \multicolumn{9}{|c|}{ Coefficients $^{\mathrm{a}}$} \\
\hline & & \multicolumn{2}{|c|}{$\begin{array}{c}\text { Unstandardized } \\
\text { Coefficients }\end{array}$} & $\begin{array}{l}\text { Standardized } \\
\text { Coefficients }\end{array}$ & \multirow[b]{2}{*}{ Q } & \multirow[b]{2}{*}{ Sig. } & \multicolumn{2}{|c|}{ Collinearity Statistics } \\
\hline \multicolumn{2}{|c|}{ Model } & $\mathrm{B}$ & Std. Error & Beta & & & Tolerance & Vif \\
\hline 1 & (Constant) & 2.441 & 1.552 & & 1.573 & .118 & & \\
\hline & $\mathrm{X} 1$ & .173 & .069 & .151 & 2.492 & .014 & .722 & 1.384 \\
\hline & $\mathrm{X} 2$ & .512 & .104 & .446 & 4.904 & .000 & .322 & 3.102 \\
\hline & X3 & .399 & .104 & .338 & 3.822 & .000 & .340 & 2.939 \\
\hline
\end{tabular}

Based on the results of data processing as seen in the table above Unstandardized Coefficients part B obtained multiple linear regression equations, namely as follows:

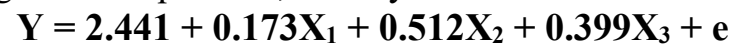

Based on these equations can be described as follows:

a.Constants (a) $=2,441$. That is, although the free variable consisting of training, discipline and communication is worth 0 then productivity in PT. Linewin is fixed at 2,441 units.

b.Coefficient $X_{1}\left(b_{1}\right)=0.173$. Variable training on productivity with a regression coefficient of 0.173 . This means that every increase in training variables is 1 unit, then pt productivity. Linewin will increase by 0.173 units.

c.Coefficient $\mathrm{X}_{2}\left(\mathrm{~b}_{2}\right)=0.512$. Variable discipline for productivity with a regression coefficient of 0.512 . This means that every increase in disciplinary variables by 1 unit, then the productivity of PT. Linewin will increase by 0.512 units.

d.Coefficient $\mathrm{X}_{2}\left(\mathrm{~b}_{2}\right)=0.399$. Variable communication to productivity with a regression coefficient of 0.399 . This means that every communication variable increases by 1 unit, then the productivity of PT. Linewin will increase by 0.399 units. 


\section{Test t (Partial)}

Based on the results of the analysis of the data shown in table 2 above, the results of the $t$ test in this study are as follows:

1.The value of the training variable $t$ count is 2,492 while the table $t$ is 1,981 , then the training has a positive and significant effect of $0.000(0.014<0.05)$. It can be stated that training has a significant effect on productivity in PT. Linewin.

2.The $t$ value of $f_{\text {the }}$ discipline variable count is 4,904 while the table $t$ is 1,981 , then the discipline has a positive and significant effect of $0.000(0.000<0.05)$. It can then be concluded that disciplinary variables have a positive and significant effect on productivity in PT. Linewin.

3.The $\mathrm{t}$ value of the communication variable count is 3,822 while the table $t$ is 1,981 so the communication has a positive and significant effect of $0.000(0.000<0.05)$. It can then be concluded that communication variables have a positive and significant effect on productivity in PT. Linewin.

\section{Test F (Simultaneous)}

Table 3. Test Result F (Simultaneous

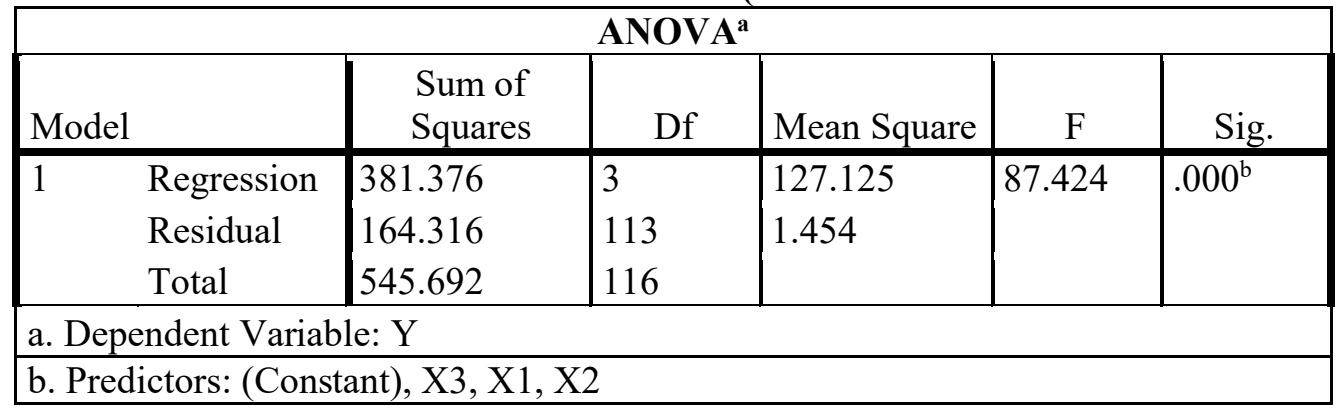

Based on the results of Test $F$, it is obtained a calculated $F$ value of 87,424 and a table $F$ value of 2.68 which means $\mathrm{F}$ count $>\mathrm{F}_{\text {of the table }}$ and a significant value of $0.000<0.05$. The results showed that simultaneous training, discipline and communication had a significant effect on employees' work productivity in PT. Linewin.

\section{Determination Coefficient}

The results of the determination coefficient in this study are as follows:

Table 4. Hypothetical Determination Coefficient Test Results

\begin{tabular}{|l|c|c|l|l|}
\hline \multicolumn{5}{|c|}{ Model Summary $^{\mathbf{b}}$} \\
\hline Model & $\mathrm{R}$ & R Square & $\begin{array}{c}\text { Adjusted R } \\
\text { Square }\end{array}$ & $\begin{array}{c}\text { Std. Error of the } \\
\text { Estimate }\end{array}$ \\
\hline 1 & $.836^{\mathrm{a}}$ & .699 & .691 & 1.206 \\
\hline \multicolumn{2}{|l|}{ a. Predictors: (Constant), X3, X1, X2 } \\
\hline \multicolumn{2}{|l}{ b. Dependent Variable: Y } \\
\hline
\end{tabular}

Based on the table above, a determination coefficient value of 0.691 is obtained. This suggests that $69.1 \%$ of productivity variables can be explained by variations in training, discipline and communication variables and the remaining $40.9 \%$ is another variable not studied in this study.

\section{CONCLUSION}

Training has an influence in improving work productivity in PT. Linewin. Pelatihan can be done by giving materi training packaged concisely and easily understood by participants. So that the trainees will be interested during the training program organized by the training, it is expected that employees will have good skills and knowledge in carrying out the activities of completing their tasks and responsibilities.

Discipline has an influence in improving work productivity in PT. Linewin. Mimposes strict sanctions on employees who often violate working time rules. This is to ensure that employees who often skip work will feel disingena for their behavior that violates the rules.

Communication has an influence in improving work productivity in PT. Linewin. Communication that should be done from the bottom up. It aims to get valid information. In addition, 
management will have a clear source of information in determining the direction of policy in PT. Linewin.

\section{ACKNOWLEDGMENTS}

The authors thanked the head of PT. Linewin has granted the necessary permissions and data sources. In addition, the author would like to thank the director of Polytechnic Superior LP3M who has given permission to the author to conduct research in PT. Linewin.

\section{REFERENCES}

[1] A. N. A. K. I. F. Umar, "Pengaruh Masa Kerja, Pelatihan Dan Motivasi Terhadap Produktivitas Kerja Karyawan Pada Pt. Bank Sulselbar Cabang Utama Makassar," Hasanuddin J. Appl. Bus. Entrep., vol. 1, no. 1, pp. 49-64, 2018.

[2] D. Y. E. Suprianto, "Pengaruh Gaya Kepemimpinan Dan Tingkat Pendidikan Terhadap Kinerja Karyawan Pada Direktorat Operasi/Produksi PT. X," Indept, vol. 4, no. 1, 2014.

[3] S. Aprilyanti, "Pengaruh Usia dan Masa Kerja Terhadap Produktivitas Kerja (Studi Kasus: PT. OASIS Water International Cabang Palembang)," J. Sist. dan Manaj. Ind., vol. 1, no. 2, p. 68, 2017.

[4] S. A. Tobari, "Pengaruh Pendidikan Dan Pelatihan Terhadap Produktivitas Kerja Karyawan Bagian Produksi Pada Pt. Semen Baturaja (Persero) Tbk Palembang," JMKSP (Jurnal Manajemen, Kepemimpinan, dan Supervisi Pendidikan), vol. 4, no. 1, p. 97, 2019.

[5] J. A. G. M. Aziz, "Pengaruh Pendidikan Dan Pelatihan (Diklat), Kedisiplinan Pegawai, dan Pengembangan Karier terhadap Produktivitas Kerja Pegawai pada Badan Kepegawaian dan Pengembangan Sumber Daya Manusia Kabupaten Soppeng," YUME J. Manag., vol. 1, no. 3, 2018.

[6] F. Pertiwi, "Pengaruh Disiplin Kerja Terhadap Produktivitas Kerja Pegawai Negeri Sipil Di Kantor Dinas Perindustrian Perdagangan Koperasi Dan Umkm Provinsi Kalimantan Timur," eJournal Adm. Negara, vol. 5, no. 1, pp. 5360-5374, 2017.

[7] S. C. S. A. Y. Nasib, "Optimalisasi Prestasi Kerja Melalui Peningkatan Disiplin, Motivasi Dan Lingkungan Kerja Pada PT. Vamrer Jaya Abadi Medan," in The 2nd Interntional Conference on Politics of Islamic Development, 2019, no. April, pp. 192-201.

[8] Harun, "Pengaruh Komunikasi Interpersonal Terhdap Produktivitas Kerja Karyawan Pada Pt Pln ( Persero ) Wilayah Sulsel, Sultra, Sulbar," UIN Alauddin Makasar, 2014.

[9] R. D. Sianturi, "Peranan Komunikasi Terhadap Produktivitas Kerja Pegawai Pada Stmik Budidarma Medan," J. Ilm. Infotek, vol. 1, no. 1, 2016.

[10] V. Gusti, "Pengaruh Komunikasi Interpersonal Terhadap Produktivitas Kerja Karyawan Grand Rocky Hotel Bukit Tinggi," Universitas Negeri Padang, 2015. 